\title{
USAHA RUMAH TANGGA NELAYAN DI DESA KEMA III KECAMATAN KEMA KABUPATEN MINAHASA UTARA
}

Helmi S. Djafar1; Lexy K. Rarung2; Christian R. Dien²

1)Mahasiswa Fakultas Perikanan dan IImu Kelautan Universitas Sam Ratulangi Manado

2)Staff Pengajar Fakultas Perikanan dan Ilmu Kelautan Universitas Sam Ratulangi Manado

Koresponden email : helmi.djafar@yahoo.com

\begin{abstract}
The purpose of this study was to determine what business diversification was chosen by the fishing community of Kema III Village, Kema District, North Minahasa District in maintaining their lives and their families and also to determine the differences and implications of business diversification chosen by fishing communities in Kema III Village, Kema District, Minahasa Regency North.

The method used in this study, namely survey. Survey research is used to collect data or information about large populations using relatively small samples. The population can be related to people, institutions, institutions, organizations and community units, etc., but the main source is people.

To maintain the economic viability of fisherman households, one of the strategies undertaken is to diversify jobs, outside of activities as fishermen. Alternative efforts by fishermen in Kema III Village to increase their household income outside the fisheries sector include construction workers, shop stalls, workshops and shops. By diversifying jobs, the fishermen's family has a meaning that is very meaningful for the sustainability of the household economy. This is related to irregularities and instability of their income from the results of fishing.
\end{abstract}

Keywords: fishermen, household businesses, household economic sustainability, diversification

\begin{abstract}
Abstrak
Tujuan penelitian ini adalah dapat menentukan diversifikasi usaha apa yang dipilih oleh masyarakat nelayan Desa Kema III Kecamatan Kema Kabupaten Minahasa Utara dalam mempertahankan hidup mereka dan keluarga dan juga untuk menentukan perbedaan dan implikasi dari diversifikasi usaha yang dipilih oleh masyarakat nelayan Desa Kema III Kecamatan Kema Kabupaten Minahasa Utara.

Metode yang digunakan dalam penelitian ini, yaitu survey. Penelitian survey digunakan untuk mengumpulkan data atau informasi tentang populasi yang besar dengan menggunakan sampel yang relatif kecil. Populasi tersebut bisa berkenaan dengan orang, instansi, lembaga, organisasi dan unit-unit kemasyarakatan dan lain-lain, tetapi sumber utamanya adalah orang.

Untuk mempertahankan kelangsungan ekonomi rumah tangga nelayan, salah satu strategi yang dilakukan adalah dengan melakukan diversifikasi pekerjaan, di luar kegiatan sebagai nelayan. Usaha alternatif yang dilakukan nelayan di Desa Kema III dalam meningkatkan pendapatan rumah tangganya di luar sektor perikanan antara lain buruh bangunan, usaha warung, bengkel dan toko. Dengan melakukan diversifikasi pekerjaan, bagi keluarga nelayan memiliki makna yang sangat berarti bagi kelangsungan ekonomi rumah tangganya. Hal ini terkait dengan ketidakteraturan dan ketidakstabilan penghasilan mereka dari hasil melaut.
\end{abstract}

Kata kunci: nelayan, usaha rumah tangga, kelangsungan ekonomi rumah tangga, diversivikasi

\section{PENDAHULUAN}

Pemanfaatan

sumberdaya

perikanan khususnya perikanan tangkap sampai saat ini masih didominasi oleh usaha perikanan rakyat yang umumnya memiliki karakteristik skala usaha kecil, aplikasi teknologi yang sederhana, jangkauan penangkapan yang terbatas di sekitar pantai dan produktivitas yang relatif masih rendah (Wulandari $d k k$, 2016). Produktivitas nelayan yang rendah umumnya diakibatkan oleh rendahnya keterampilan dan pengetahuan serta penggunaan alat penangkapan maupun perahu yang masih sederhana sehingga efektifitas dan efisiensi alat tangkap dan penggunaan faktor-faktor produksi lainnya belum optimal. Keadaan ini sangat berpengaruh terhadap pendapatan yang diterima oleh nelayan dan pada akhirnya mempengaruhi pula tingkat kesejahtaraannya (Ginting, 2010).

Faktor pembatas nelayan terhadap kondisi cuaca akan berdampak pada nelayan tidak dapat lagi melakukan 
aktivitas penangkapan ikan pada cuaca yang tidak baik. Hal ini menyebabkan nelayan tidak akan mendapatkan pendapatan dari hasil penangkapan ikan. Kondisi ini perlu diantisipasi nelayan, jika tidak maka nelayan dan anggota keluarga akan mengalami kekurangan dan bahkan kelaparan. Salah satu bentuk mengatasi faktor pembatas ini, yaitu melakukan diversifikasi. Diversifikasi diartikan sebagai strategi perusahaan untuk beroperasi pada beberapa segmen industri (multi-segment), baik pada industri yang terkait (related) ataupun tidak terkait (unrelated) Montgomery (1994) dalam Vanarasi (2005). Diversifikasi pekerjaan merupakan sebuah solusi yang dapat diandalkan untu8k mengubah pola piker nelayan supaya tidak terlalu terpaku dengan penghasilan mereka dari kegiatan melaut. Jika cuaca sedang buruk untuk melaut, mereka tetap bisa memperoleh penghasilan dengan cara melakukan pekerjaan alternative yang lain. Pekerjaan yang bisa dilakukan, antara lain dengan menjadi pemandu wisata, bertani, pedagang kecil (misalnya penjual kripik dan lainnya), tukang bangunan atau yang lainnya.

Diversifikasi ini diharapkan dapat memberikan alternatif bagi nelayan Desa Kema III, dalam hal ini nelayan tradisional, dimana dengan usaha diversifikasi ini bagi nelayan memiliki peluang untuk memperoleh pendapatan apabila tidak melaut, karena ada sumber pendapatan lain yang dapat menopang kehidupan mereka dan keluarga.

\section{METODE PENELITIAN}

Metode yang digunakan dalam penelitian ini, yaitu survey. Penelitian survey digunakan untuk mengumpulkan data atau informasi tentang populasi yang besar dengan menggunakan sampel yang relatif kecil. Populasi tersebut bisa berkenaan dengan orang, instansi, lembaga, organisasi dan unitunit kemasyarakatan dan lain-lain, tetapi sumber utamanya adalah orang.

Survey adalah suatu metode untuk meneliti status kelopok manusia, suatu objek, suatu set kondisi, suatu sistem pemikiran ataupun suatu kelas peristiwa pada masa sekarang. Tujuan dari penelitian deskriptif ini adalah untuk membuat deskripsi, gambaran atau lukisan secara sistematis, faktual dan akurat mengenai fakta-fakta, sifat-sifat serta hubungan antar fenomena yang diselidiki (Nazir, 2003).

Pengumpulan data dilakukan dengan mengajukan pertanyaanpertanyaan dan wawancara serta menggunakan kuisioner, terhadap responden nelayan sebanyak 10 responden yang ada di Desa Kema III Kecamatan Kema Kabupaten Minahasa Utara.

Analisis data yang dalam penelitian ini menggunakan analisis deskriptif kuantitatif dan deskriptif kualitatif. Analisis deksriptif kuantitatif adalah pengumpulan data berbentuk angka-angka, sedangkan analisis deksriptif kualitatif adalah pengumpulan data berbentuk kata-kata.

Tenik analisis data menurut Hasan (2006) adalah memperkirakan atau menentukan besarnya pengaruh secara kuantitatif dari suatu (beberapa) kejadian terhadap suatu (beberapa) kejadian lainnya, serta memperkirakan/ meramalkan kejadian lainnya. Kejadian dapat dinyatakan sebagai perubahan nilai variabel. Proses analisis data dimulai dengan menelaah seluruh data yang diperoleh baik melalui hasil kuesioner dan bantuan wawancara. 


\section{HASIL PENELITIAN}

\section{Diversifikasi Pekerjaan Nelayan}

Diversifikasi pekerjaan merupakan strategi yang umum dilakukan di banyak komunitas nelayan dan sifatnya terbatas. Jenis peluang kerja yang yang bisa dilakukan oleh nelayan sangat tergantung pada sumberdayasumberdaya yang tersedia di desa nelayan dan sumberdaya nelayan itu sendiri. Jenis pekerjaan nelayan selain sebagai nelayan di Desa Kema 3 Kecamatan Kema Kabupaten Minahasa Utara antara lain: Buruh bangunan, usaha warung, bengkel dan toko.

\section{Pilihan Pekerjaan di Luar Usaha Nelayan}

Pilihan jenis pekerjaan di luar usaha nelayan dari responden di Desa Kema 3, yaitu buruh bangunan, usaha warung, bengkel dan toko. Jenis pekerjaan di luar usaha nelayan dari responden nelayan di Desa Kema 3 , dapat dilihat sebagai berikut:

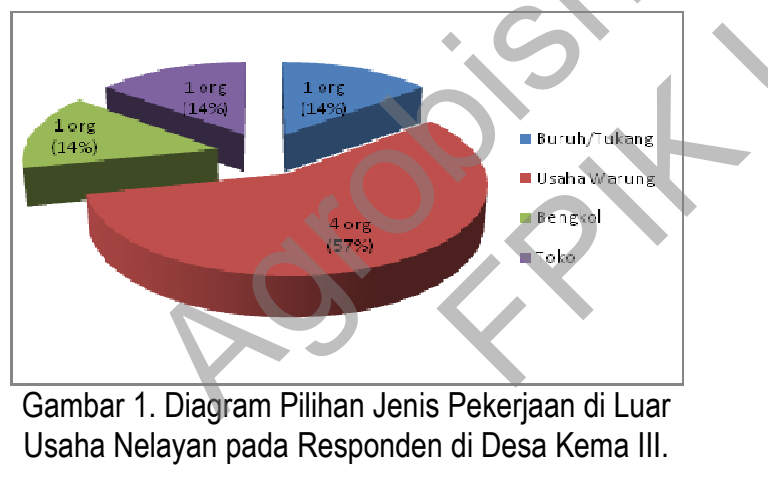

Alasan Bekerja di Luar Usaha Nelayan melakukan diversifikasi pekerjaan merupakan aktivitas yang penting untuk dilakukan, terkait dengan keterbatasan aktivitas melaut yang tidak bisa dilakukan sepanjang tahun, terutama bagi nelayan perorangan yang aktivitas melautnya sangat tergantung pada musim. Karena itu umumnya nelayan tidak hanya mengharapkan penghasilan dari melaut, sebab penghasilan melaut selama beberapa bulan tidak bisa menutupi kebutuhan hidup sepanjang tahun. Saat musim ikan, penghasilan yang diperoleh nelayan dapat memenuhi kebutuhan hidup nelayan, sebagian di antara mereka menyisihkan sebagian penghasilannya untuk ditabung di Koperasi atau Bank. Di saat musim paceklik biasanya tabungan tersebut diambil untuk menutupi kebutuhan hidup sehari-hari mereka. Karena itu untuk menutupi kebutuhan hidup selama musim paceklik, nelayan melakukan pekerjaan di luar sebagai nelayan.

Dengan melakukan diversifikasi pekerjaan, bagi nelayan memiliki tujuan yang sangat bermanfaat bagi kelangsungan ekonomi rumah tangganya. Hal ini terkait dengan ketidakteraturan dan ketidakstabilan kegiatan mereka dalam kegiatan melaut yang berakibat pada penghasilan dari hasil melaut.

\section{Pendapatan Diversifikasi Nelayan}

Pendapatan hasil diversifikasi nelayan di Desa Kema III Kecamatan Kema dapat dilihat pada tabel berikut.

Perlu diketahui usaha bengkel terdapatan di pusat desa, sedangkan usaha toko lokasinya diseputaran TPI, dan usaha warung ada disamping rumah pemilik alat tangkap.

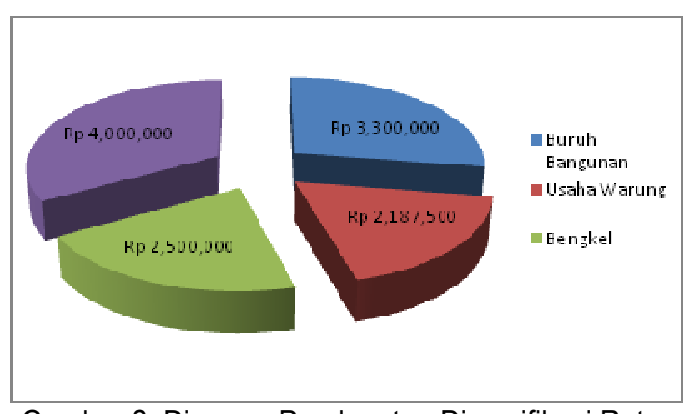

Gambar 2. Diagram Pendapatan Diversifikasi Ratarata per Bulan Nelayan Desa Kema III 


\section{KESIMPULAN DAN SARAN \\ Kesimpulan}

1. Jenis diversifikasi usaha yang dilakukan nelayan di Desa Kema III dalam meningkatkan pendapatan rumah tangganya di luar sektor perikanan antara lain buruh bangunan, usaha warung, bengkel dan toko.

2. Adanya diversifikasi uasaha ternyata membantu perekonomian rumah tangga nelayan pemilik.

\section{Saran}

1. Pemerintah diharapkan untuk memiliki perhatian dan kepedulian terhadap penyediaan lapangan pekerjaan berupa tempat pekerjaan oleh Pemerintah Daerah dapat membantu nelayan dalam menghadapi musim paceklik karena cuaca dan musim ikan.

2. Diharapkan bantuan berupa modal untuk pengembangan dan menciptakan diversifikasi usaha nelayan ketika tidak melaut.

\section{DAFTAR PUSTAKA}

Anna, S. 2006. Analisis Ekonomi Kawasan Konservasi Laut: Optimalisasi dan Dampak Sosial Ekonomi Pada Perikanan. Jurnal Kebijakan dan Riset Sosial Ekonomi Kelautan dan Perikanan. Badan Riset Kelautan dan Perikanan. Departemen Kelautan dan Perikanan. Jakarta.

Ali, 2010. Konsep Dukungan Keluarga. Jakarta. Salmeba Medika.

Departemen Kelautan dan Perikanan. 2002.Tentang melakukan operasi penangkapan ikan di perairan umum.

Ginting. 2010. Himpunan Ahli Pengelolaan Pesisir Indonesia (HAPPI). Organisasi dan Pengembangan SDM HAPPI.
Hariadi, Bambang. 2005. Strategi Manajemen. Jakarta. Bayumedia Publishing

Harmaizar, Z. 2008. Menangkap Peluang Usaha. Bekasi: CV. Dian Anugrah Prakasa.

Kaparang, M.C, D.R.R. Aling dan G.O. Tambani. 2015. Pengaruh Diversifikasi Usaha Terhadap Pendapatan Rumah Tangga Nelayan Tradisional di Kawasan Reklamasi Kota Manado Provinsi Sulawesi Utara. Jurnal AKULTURASI, Program Studi Agrobisnis Perikanan; Vol. 3 No. 5 April 2015. Unsrat Manado. 7 hal.

Kusnadi, M.A. 2002. Konflik Sosial Nelayan, Kemiskinan dan Perebutan Sumber Daya Perikanan. Yogyakarta LkiS.

Lailatin F, M. Primyastanto dan OS. Darmawan. 2007. Analisis Bioekonomi Model Gordon Schaefer Sumberdaya Ikan Lemuru di Parairan Selat Bali. Fakultas Perikanan. Skripsi. Universitas Brawijaya. Malang.

Lupitasari, Dewi dan Marsono. 2013. Diversifikasi Perusahaan dan Manajemen Laba. Fakultas Ekonomi dan Bisnis. Universitas Diponegoro.

Muhammad, S. 2000. Ekonomi Rumah Tangga dan Pemanfaatan Sumberdaya Perikanan di Jawa Timur, Suatu Analisa Simulasi Kebijakan. Disertasi. IPB. Bogor.

Subri, M. 2005. Ekonomi Kelautan. Raja Grafindo Persada. Jakarta.

Suryana, A., 1995. Diversifikasi Pertanian dalam Proses Mempercepat Laju Pembangunan Nasional. Pustaka Sinar Harapan Jakarta.

Vanarasi, P.M. 2005. Diversification Strategy and Firm Performance. IIMB Management Review.

Verawati, Diana. 2012. Pengaruh Diversifikasi Operasi, Diversifikasi Geografis, Leverage dan Struktur Kepemilikan Terhadap Manajemen Laba. Skripsi Universitas Diponegoro. Semarang.

Wulandari, N.A., N. Jusuf, O. Pontoh, 2016. Strategi Nelayan Dalam Memenuhi Kebutuhan Rumah Tangga (Studi Kasus di Desa Tateli Dua Kecamatan Mandolang Kabupaten Minahasa Provinsi Sulawesi Utara. Jurnal AKULTURASI Program Studi Agrobisnis Perikanan. Vol. 4 No. 1 April 2016. Unsrat. Manado.

Yuliati, Y. dan P. Mangku. 2003. Sosiologi Pedesaan. LAPPERA Pustaka Utama Yogyakarta. 